ISSN 1979-5572 (print) | ISSN 2541-6480 (online)

http://ejurnal.iainpare.ac.id/index.php/kuriositas

\title{
KURIOSITAS
}

Media Komunikasi Sosial dan Keagamaan

\begin{tabular}{lll}
\hline Volume 13 & No.2, Desember 2020 & Halaman 198-218 \\
\hline
\end{tabular}

\section{The Role of Islamic Communication in Responding to the Human Rights Issues in Indonesia}

\author{
Hamdan \\ Universitas Al Asyariah Mandar \\ hamdanunasman@gmail.com
}

\begin{abstract}
This article aims to describe the role of Islamic communication in addressing human rights issues especially in Indonesia. The problems are explained in a descriptive qualitative method by exploring the Islamic conception of human rights and the role of Islamic communication in upholding it. The results showed that Islam has a teaching respect for human rights that can be explored from various sources of Islamic teachings. Thus, Muslims must be proactive people of encouraging the growth of awareness of human rights. In this context, Islamic communication gets its urgency. The da'i, both institutionally and individually, must have the ability to become expert in understanding the human rights issues. Muslims must be actively involved in today's world, so that they should be the important part and contribute positively in order to make the Islamic campaign as rahmatan li al-'alamin.
\end{abstract}

Keywords: Human Rights; Rahmatan lil 'alamin; Islamic Communication.

\begin{abstract}
ABSTRAK
Artikel ini betujuan untuk mendeskripsikan bagaimana peran komunikasi Islam dalam menyikapi persoalan HAM khususnya di Indonesia? Penguraian masalah dilakukan secara deskriptif kualitatif, yakni mengeksplorasi dan menjelaskan konsepsi Islam tentang HAM dan peran komunikasi Islam dalam menegakkannya. Hasil penelitian menunjukkan, Islam memiliki ajaran penghargaan terhadap Hak Azasi Manusia yang dapat dieksplor dari berbagai sumber ajaran Islam. Dengan demikian, umat Islam wajib menjadi bagian aktif untuk mendorong tumbuhnya kesadaran terhadap hak-hak kemanusiaan. Dalam konteks inilah komunikasi Islam
\end{abstract}


memperoleh urgensitasnya. Para $d a^{\prime} i$ baik secara kelembagaan maupun individu harus memiliki kemampuan penguasaan materi atas isu-isu HAM. Umat Islam harus aktif terlibat dalam proses global yang tengah berlangsung, menjadi bagian penting dan berkontribusi positif, baik di Indonesia maupun dalam masyarakat global, sembari melakukan kampanye Islam rahmatan li al-'alamin.

Kata Kunci: Hak Asasi Manusia Rahmatan lil ‘alamin; Komunikasi Islam.

\section{PENDAHULUAN}

Secara umum terma Hak Asasi Manusia (HAM) dimaknai sebagai hak-hak yang melekat pada manusia sejak lahir, sesuatu yang dibawa dan dimiliki sebagai pemberian Tuhan. Hak ini berlaku pada setiap manusia tanpa memperhatikan faktor-faktor pembeda seperti ras, agama, warna kulit, kasta, kepercayaan, jenis kelamin, atau kebangsaan. Mengacu pada makna tersebut, Islam sesungguhnya memiliki konsep serta ajaran yang sangat prinsip untuk menghargai dan menegakkan HAM. Dengan demikian umat Islam idealnya tidak menjadi elemen yang kontra produktif atau alergi dengan isu HAM, dan mestinya menjadi elemen penting dalam penegakannya. Hal ini memungkinkan dengan mendoorong peran komunikasi Islam dalam mengkampanyekan isu HAM.

Konsepsi serta ajaran HAM, fondasinya pertama kali telah dibangun oleh Islam sejak kemunculannya pada abad ke-6 Masehi. Sementara Amerika Serikat mengembangkannya baru pada abad ke-18 M, melalui American Declaration of Independence (1776) dan American Bill of Rights (1791). Perancis menggunakannya abad ke-18 M, melalui Declaration des Droits de l'home et du Citoyen (1789). Jauh setelahnya, Rusia melalui UUD (1937) dan sepuluh tahun kemudian PBB mendeklarasi The Universal Declaration of Human Rights (UDHR) pada 10 Desember 1948 (Washil, Izzuddin \& Ahmad 2017), (Nawawi 2017). 
Eggi Sudjana mengemukakan bahwa pada hakekatnya manusia memiliki dua hak fundamental yang ada pada setiap diri yaitu hak persamaan dan hak kebebasan. Mengacu pada kedua hak tersebut lahirlah sejumlah hak-hak turunanyang mencakup segala hak-hak dasar, seperti; hak hidup, hak beragama, hak berpendapat, hak persamaan di depan hukum, hak berpenghidupan yang layak, hak mendapatkan kecerdasan intelektual, hak milik dan lain sebagainya (Sudjana 2002).

Apa yang dijelaskan Eggi Sudjana tersebut kurang tepat, sebab hak persamaan dan hak kebebasan masih merupakan turunan dari "hak hidup". Hak hiduplah yang menjadi pokok dari semua hak. Tuhan menciptakan manusia dengan memberikan hidup kepada siapa pun, dan karenanya setiap orang berhak menjalani hidup itu dengan baik. Dalam rangka menjaga dan menjalani hak hidup yang baik inilah, muncul hak turunan lainnya yang sangat bervariatif. Misalnya hak mendapatkan hidup layak, pendidikan, kebebasan mengajukan pikiran dan ekspresi, persamaan di depan hukum, atau lebih umum lagi disebut hak ekosob (ekonomi, sosial, budaya).

Keberadaan HAM berkembang secara proporsional (seimbang, sebanding) dengan eksistensi manusia, sesuai dengan kemampuan pemikirannya serta perkembangan lingkungannya. Kejahatan HAM senantiasa menjadi bayang-bayang kelam bentang sejarah peradaban manusia. Dapat dilihat betapa Jerman memikul beban moral atas kejahatan HAM masa lalu atas perlakuan Hitler. Jepang menanggung beban masa kolonial atas kejahatan HAM oleh militernya. Begitu juga Rwanda, Kamboja, Irak, Amerika Serikat di Afghanistan, Bosnia Herzegovina, tahanan Guantanamo, Indonesia, dan lain-lain. 
Walaupun konsep HAM yang dikenal saat ini lahir antara abad ke17 dan ke-18 M lalu dikembangkan oleh Eropa dan Amerika, namun secara mendasar konsep serupa dapat dilacak mundur sampai ke tradisi-tradisi luhur yang hidup di jaman dulu. Jauh sebelum kemunculan konsep HAM yang sekular-rasional, tradisi keagamaan yang pernah mengisi peradaban kuno telah memberikan semacam pondasi bagi pengembangan HAM selanjutnya. Tradisi keagamaan tersebut menjadi alternatif bagi penegakan HAM yang lebih positif meskipun belum cukup kuat untuk dijadikan fondasi HAM bagi masyarakat plural. Olehnya itu, tidak keliru bila dipandang bahwa pendekatan sejarah masih diperlukan dalam mengkaji persoalan HAM (Rukmana 2019).

Kuatnya pengaruh opini internasional tidak dapat dipungkiri mendorong keberadaan pegadilan HAM di Indonesia yang secara hukum berdasar pada Undang-undang No. 26 Tahun 2000. Kenyataan ini, memicu kesadaran Indonesia sebagai negara agar menanggalkan pola laku Orde Lama maupun Orde Baru yang dipandang masih kurang kuat mengimplemetasikan HAM dan demokrasi. Pasca Orba, Indonesia nampak mulai mengubah sikap dalam merespon isu HAM. Hal ini diwujudkan malaui pencabutan sejumlah Undang-undang yang dipandang tidak lagi memiliki relevansi sosial-politik dan selanjutnya merumuskan dan memberlakukan Undang-undang yang menghargai serta menjamin nilainilai HAM dan demokrasi. Tidak hanya memberi jaminan ketentuan tentang HAM dengan mengamandemen UUD 1945, Indonesia juga memberlakukan sejumlah Undang-undang yang berkaitan dengan HAM di antaranya UU Nomor 39 Tahun 1999 tentang HAM, UU Nomor 26 Tahun 2000 tentang Pengadilan HAM, serta meratifikasi sejumlah konvensi internasional terkait HAM (Suteng 2006),(Triwahyuningsih 2018). 
Penghayatan akan urgensi penghormatan dan penghargaan terhadap sesama manusia serta kesadaran akan urgensi HAM, lahir secara koheren dengan kesadaran human centred development, kesadaran akan pentingnya memposisikan manusia sebagai titik sentral dalam pembangunan. Konsep HAM berakar pada penghargaan terhadap martabat kemanusiaan, sehingga manusia didudukkan sebagai mahluk yang begitu bernilai. Memposisikan manusia sebagai subjek dan bukan objek. Memandang manusia sebagai makluk yang dihargai dan dihormati tanpa dikacaukan oleh perbedaan jenis kelamin, ras, ideologi, suku bangsa, bahasa dan agama (Pengestuti, Naniek \& Khamdan 2017).

HAM memberi ajaran prinsip universal berupa persamaan dan kebebasan manusia. Dengan begitu sejatinya tidak boleh ada kekerasan, diskriminasi dan eksploitasi terhadap sesama manusia, serta segala bentuk pembatasan dan pengungkungan terhadap kebebasan dasar manusia. Dari kerangka inilah pentingnya mengelaborasi nilai-nilai universal HAM dalam sudut pandang Islam dan mengkomunikasikannya secara baik di tengah masyarakat, khususnya di Indonesia.

Sejak kedatangannya, Islam telah mengajarkan dan menerapkan penghapusan perbudakan sebagai salah satu aspek utama dalam isu hak asasi manusia saat ini. Islam mengajarkan umatnya agar menghormati dan mengakui hak-hak hidup seseorang, sebab setiap individu manusia masing-masing telah diberikan kemuliaan oleh Allah SWT, sebagaimana dijelaskan dalam Q.S. Al-Isra'/17:70 sebagai berikut;

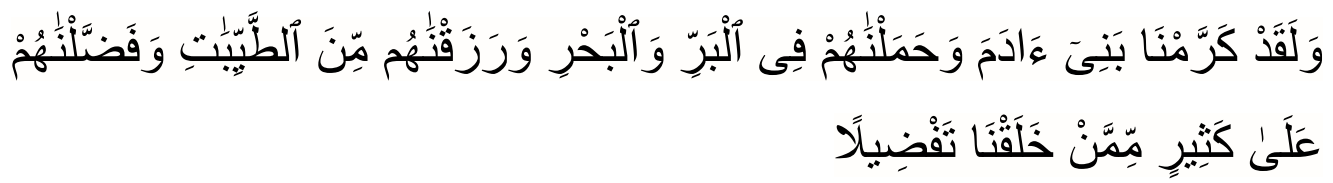

Terjemahnya: 
"Dan sesungguhnya telah kami muliakan anak-anak Adam, Kami angkut mereka di daratan dan di lautan, Kami beri mereka rezki dari yang baik-baik dan Kami lebihkan mereka dengan kelebihan yang sempurna atas kebanyakan makhluk yang telah Kami ciptakan".

Islam mengajarkan bahwa setiap orang harus menghormati setiap orang lainnya, tidak saling merendahkan satu dengan yang lain, dan bahkan tidak merendahkan diri sendiri. Hal ini misalnya dijelaskan dalam Q.S. Al-Hujurat/49:11 sebagai berikut:

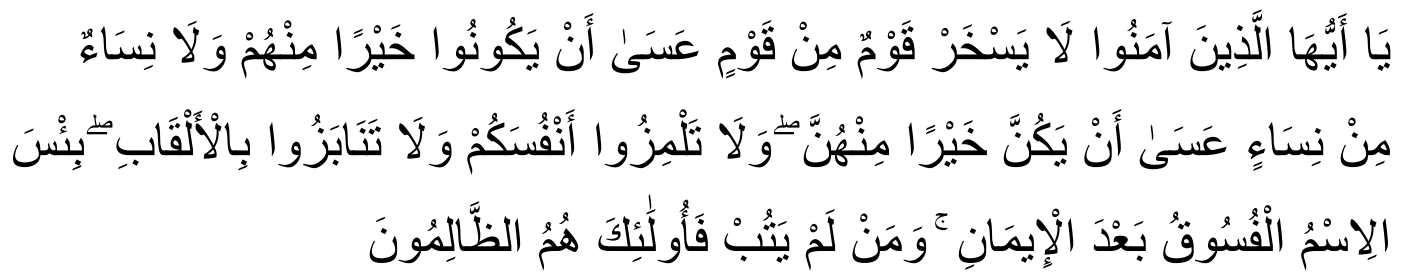

Terjemahnya:

"Hai orang-orang yang beriman, janganlah sekumpulan orang laki-laki merendahkan kumpulan yang lain, boleh jadi yang ditertawakan itu lebih baik dari mereka. Dan jangan pula sekumpulan perempuan merendahkan kumpulan lainnya, boleh jadi yang direndahkan itu lebih baik. dan janganlah suka mencela dirimu sendiri dan jangan memanggil dengan gelaran yang mengandung ejekan. seburuk-buruk panggilan adalah (panggilan) yang buruk sesudah iman dan barangsiapa yang tidak bertobat, Maka mereka Itulah orang-orang yang zalim".

Islam atau lebih tepatnya umat Islam, khususnya di Indonesia seyogyanya ikut berperan aktif dan memberi kontribusi positif terhadap Negara dan agama dalam menyelesaikan masalah-masalah HAM. Islam mestinya dapat dipahami oleh seluruh lapisan masyarakat sebagai agama yang menjunjung tinggi nilai-nilai kemanusiaan. Dan sebaliknya tidak memandang isu-isu HAM dengan mengkonfrontasi pemikiran Barat dan Islam, sebab Islam ditujukan untuk menjadi rahmat bagi seluruh umat manusia (Atqiya 2014).

Dalam konteks inilah diperlukan peran maksimal dan konstruktif dari komunikasi Islam atau yang biasa dikenal dengan istilah Dakwah. 
Dengan berperannya komunikasi Islam, ajaran-ajaran Islam yang rahmatan li al-alamin khususnya dalam aspek HAM, sejatinya dapat diterima dan diresapi oleh seluruh masyarakat tanpa memandang apa agamanya. Penting untuk merumuskan konsep dan strategi komunikasi Islam dalam menanamkan nilai-nilai HAM di tengah masyarakat.

\section{PEMBAHASAN}

\section{Konsepsi HAM dalam Ajaran Islam}

Islam disebut sebagai agama universal serta komprehensif sebab isi ajaran Islam mancakup serta melingkupi segenap dimensi waktu dan ruang (kapan dan di mana pun) kehidupan manusia. Konsep dimaksud yakni aqidah, ibadah, serta muamalat. Dengan ketiga dimensi ini, ajaran Islam menjadi kompleks dan cukup komplit; tidak hanya mengandung ajaran iman dan tauhid, tetapi juga memiliki dimensi ajaran yang didasari oleh ketentuan hukum berupa syari'at atau fiqhi.

Ada dua konsep dasar dalam Islam terkait dengan hak, menurut Abu al'Ala al-Maududi yakni; pertama, hak dasar manusia (huquq al-insan al-dharuriyyah); dan kedua, hak Allah (huquq Allah) (Al-Maududi 1998). Jika hendak dilihat dari tingkatannya, ajaran Islam memiliki tiga bentuk HAM. Pertama, disebut sebagai darury, atau hak-hak dasar (premier), yakni sesuatu yang dipandang sebagai hak paling dasar. Sebab itu, bila mana hak ini dilanggar, tidak sekedar hanya mengakibatkan kesengsaraan bagi manusia tetapi juga kehilangan eksistensi dan bahkan harkat kemanusiaannya. Contohnya, bila seseorang dilanggar hak hidupnya, maka orang tersebut sama artinya telah mati. Kedua, disebut sebagai hajy, hak sekunder, yakni hak yang apabila tidak terpenuhi akan mengakibatkan hilangnya hak-hak primer atau elementer tadi. Misalnya, seseorang yang kehilangan hak memperoleh kebutuhan sandang serta pangan yang layak, mengakibatkan 
pada hilangnya hak hidup yang primer. Ketiga, disebut tahsiny, hak tersier, yakni semua hak yang posisinya lebih rendah dari hak sekunder (Alfaruqi 2017).

Ajaran Islam tentang HAM tentunya tidak sulit ditemukan pada dua sumber pokok ajaran Islam, yakni al-Qur'an dan al-Hadits. Kedua sumber ini berfungsi sebagai sumber normatif sekaligus sebagai sumber praksis dalam kehidupan umat Islam. Pada praktiknya, HAM dalam Islam dapat ditandai dengan dua peristiwa penting yakni Piagam Madinah atau alDustur al-Madinah dan Deklarasi Cairo atau The Cairo Declaration (Rosyada 2005), (Washil, Izzuddin \& Ahmad 2017). Kedua peristiwa tersebut secara singkat dapat diuraikan sebagai berikut:

\section{al-Dustur al-Madinah}

Ajaran pokok dalam al-Dustur al-Madinah atau Piagam Madinah yakni: Pertama, interaksi yang baik terhadap sesame manusia, baik antar pemeluk Islam maupun terhadap non Muslim. Kedua, sesama warga saling bantu-membantu dalam menghadapi musuh bersama. Ketiga, membela siap pun yang teraniaya. Keempat, saling nasehat-menasihati. Dan kelima saling menghormati kebebasan beragama. Dasar ini telah diletakkan pada Piagam Madinah sebagai landasan kehidupan bernegara bagi masyarakatnya yang majemuk saat itu.

\section{a. Deklarasi Cairo (The Cairo Declaration), memuat ketentuan HAM dalam Al-Qur'an yakni;}

1. Hak persamaan dan kebebasan (Q.S. al-Nisa: 58, 105, 107, 135, alIsra: 70, dan al-Mumtahanah: 8);

2. Hak hidup (Q.S. al-Maidah: 45 dan al-Isra': 33);

3. Hak perlindungan diri (Q.S. al-Balad: 12-17, al-Taubah: 6);

4. Hak kehormatan pribadi (Q.S. al-Taubah: 6); 
5. Hak keluarga (Q.S. al-Baqarah: 221, al-Rum: 21, al-Nisa: 1, alTahrim: 6);

6. Hak keseteraan wanita dan pria (Q.S. al-Baqarah: 228 dan alHujurat: 13);

7. Hak anak dari orang tua (Q.S. al-Baqarah: 233 dan al-Isra: 23- 24);

8. Hak mendapatkan pendidikan (Q.S. al-Taubah: 122, al-'Alaq: 1$5)$;

9. Hak kebebasan beragama (Q.S. al-Kafirun: 1-6, al-Baqarah: 136 dan al-Kahfi: 29);

10. Hak kebebasan mencari suaka (Q.S. al-Nisa: 97, al-Mumtahanah: 9);

11. Hak memperoleh pekerjaan (Q.S. al-Taubah: 105, al-Baqarah: 286, al-Mulk: 15);

12. Hak memperoleh perlakuan yang sama (Q.S. al-Baqarah: 275-278, al-Nisa 161, Ali 'Imran: 130);

13. Hak kepemilikan (Q.S. al-Baqarah: 29, al-Nisa: 29); dan

14. Hak tahanan (Q.S. al-Mumtahanah: 8).

Imam al-Syathibi mengemukakan bahwa, pada prinsipnya HAM dalam Islam mengacu pada al-dharuriyat al-khamsah atau juga biasa disebut al-huquq al-insaniyah fi al-islam yakni hak-hak manusia dalam Islam (Kasdi 2014), (Suhaili 2019). Lima hal pokok yang dikemukakan oleh al-Syathibi yang wajib ditegakkan oleh setiap pribadi yaitu:

Menjaga agama (hifdz al-din). Dapat dilihat dalam soal perang, bahwa argumen diwajibkannya perang dengan jalan jihad, hanya jika perang itu bertujuan untuk melawan musuh atau untuk tujuan yang senada. Dari pemaknaan di atas dapat dijelaskan bahwa; pertama, Islam menjaga hak dan kebebasan menghayati dan menjalankan keyakinan 
seseorang serta beribadah. Artinya bahwa tiap muslim memiliki hak atas agama dan mazhabnya, dan karena hak itu, ia tidak boleh dipaksakan untuk mengikuti atau meninggalkan agama tersebut. (Q.S. al-Baqarah: 256, dan Q.S. Yunus: 99). Kedua, Islam menjaga rumah-rumah ibadah baik milik muslim maupun non muslim, menjaga kehormatan syiar mereka. Lebih dari itu bahkan Islam membolehkan perang demi menjaga kebebasan beribadah (Q.S. al-Hajj: 39-40). Hal ini menjelaskan Islam begitu menghargai sikap toleransi dengan prisip bahwa orang-orang kafir dzimmi yang hidup dalam kekuasaan negara Islam, mereka berada dalam tanggungan negara sebagaimana orang-orang muslim lainnya. toleransi dalam hal ini terbatas pada bidang mu'amalah, tidak pada bidang 'ubudiyah (Q.S. al-Kafirun: 1-6).

Menjaga jiwa (hifdz al-nafs). Dapat dirujuk pada hal qishash. Dalil wajibnya qishash, berdasar pada Q.S. al-Baqarah:178-179) di antaranya menjaga kebebasan dan kemuliaan jiwa, Islam sangat menghormati jiwa. Karena hanya Allah sajalah Sang pemberi kehidupan dan Dia pulalah yang mengambilnya (Q.S. al-Mulk: 2 dan al-Isra: 33).

Menjaga akal (hifdz al-'aql). Dapat dilihat pada soal khamar atau zat yang memabukkan, atas dalih diharamkannya setip zat atau benda yang mengakibatkan mabuk, seperti narkotika dan sejenisnya. Diketahui bahwa akal merupakan alat vital untuk memperoleh pengetahuan, jalan bagi hidayah dan menjadi media pencapaian kebahagiaan manusia di dunia dan akhlirat. Peran manusia sebagai khalifah fi al-ardh dapat dijalankan oleh manusia melalui akalnya. Dan manusia dapat menjadi berbeda dengan makhluk lain yang ada di alam inijuga karena akalnya. Atas akal pulalah, manusia dimuliakan Allah dari makhluk lain (QS. al-Isra':70). Karenanya Islam begitu ketat menjaga dan melindungi akal, dengan sangat ketat 
menentukan sanksi atas pelanggaran yang menyebabkan rusaknya akal. Dapat dilihat dalam soal meminum khamr (QS. al-Nisa':43 dan al-Ma'idah: 90) dan penggunaan benda-benda lain yang menurut kebiasaan dapat menyebabkan rusak atau hilang akalnya.

Menjaga harta (hifdz al-mal). Dapat dilihat dalam hal pencurian, suap, riba, serta mengambil milik orang dengan cara batil. Diketahui bahwa Harta adalah satu di antara inti kebutuhan hidup. Manusia tidak mungkin dijauhkan dengan harta (Q.S. al-Kahfi: 46). Adapun cara memperoleh harta harus dengan kerja dan usaha (kasb) atau melalui proses mawarits. Sebab itulah Islam melarang umatnya mencari dan mendapatkan harta dengan jalan batil (Q.S. al-Baqarah: 188, Al-Nisa': 29, al-Baqarah: 275-276, alBaqarah: 278-280). Islam dengas tegas melarang perbuatan mencuri (Q.S. al-Maidah: 38).

Menjaga keturunan (hifdz al-nasl). Dapat dilihat dari dalih haramnya zina dan qadzaf. Dengan larangan itu, Islam sangat menganjurkan pernikahan bagi mereka yang dipandang sanggup melakukannya guna menjaga kehormatan, keturunan, dan harta. Hal ini guna menegakkan secara kukuh aturan-aturan, serta mengyomi dan memberikan jaminan kehidupan.

Bagi setiap muslim, lima hal pokok di atas mesti dirawat untuk membina kehidupan yang manusiawi, melalui mengamalkan sikap saling menghormati antar sesama individu serta individu dengan kelompok keil maupun yang lebih besar seperti negara.

Walau Islam mempunyai konsepsi yang dapat dianggap cukup dalam aspek HAM, tetapi tuntunan yang baik itu tidak disosialisasikan secara dinamis melalui aktivitas dakwah yang terencana, ajaran-ajaran yang baik itu tidak mungkin dapat dimengerti dan dihayati secara baik oleh 
masyarkat secara umum. Salah satu yang dapat dikemukakan misalnya, problem kekurang-pahaman masyarakat Barat secara umum terhadap kandungan ajaran Islam, misalnya terhadap isu HAM dan isu kontemporer lainnya. Keadaan ini justru membuat misunderstanding atas Islam dan bahkan menggencarkan 'tuduhan' negatif. Islam dipandang tidak memiliki kompatibilitas terhadap perkembangan jaman, kondisi kontemporer terutama bila dihadapkan dengan isu HAM

Tuduhan-tuduhan negatif itu misalnya, sitem pemerintahan Islam berbentuk monarki-teokrasi sehingga rakyat hanya menjadi pelayan kepentingan penguasa. Hal ini jelas bertentangan dengan sistem pemerintahan demokrasi. Islam lebih meninggikan derajat laki-laki daripada kaum hawa. Contohnya dalam urusan waris, Islam melebihkan laki-laki dengan menjadikannya qawwamun. Pandangan ini dibenturkan dengan isu persamaan dan kesetaraan laki-laki dan perempuan. Hukum potong tangan dalam Islam juga dipandang merupakan pelanggaran HAM.

Setidaknya ada dua kisah yang dapat dilihat, ungkap Ebrahim Moosa yang dikutip oleh Syamsul Arifin, yang terkandung bukti yang menguatkan secara kompatibel antara Islam dan HAM. Pertama, isi pidato Rasulullah dalam pelaksanaan haji wada' yang sekaligus sebagai pidato perpisahan, yang menegaskan kembali visi Islam atas perlindungan terhadap hak dasar manusia. Menurut Moosa, substansi dari pidato tersebut, sejatinya merupakan penegasan terhadap ajaran Islam yang terkandung dalam al-Qur'an, tentang perlindungan martabat serta kehormatan manusia, dan pemilihan harta. Kedua, beberapa kebijakan khalifa al-rasyidin dalam menindak pelanggaran HAM. Sebagai contoh adalah tindakan Khalifah Umar ibn Khattab yang menegur Gubernur 
Mesir, Amr ibn Ash ketika memutuskan sanksi hukum tanpa melewati proses pengadilan. Dua histori di atas, acapkali menjadi rujukan bagi umat Islam guna memperkokoh argumen teologis yang mengkorelasikan antara ajaran Islam dengan HAM di era kontemporer (S. Arifin 2011).

Perkembangan pemikiran yang demikian maju-bahkan dalam perpektif tertentu cendrung liar, para $d a^{\prime} i$ atau praktisi dakwah dituntut agar benar-benar mampu memahami perkembangan. Praktisi dakwah dituntut agar lebih bersungguh-sugguh mempersiapkan segala yang dibutuhkan seperti materi dakwah, media dakwah, serta metode yang baik, cermat dan tepat. Diperlukan kemampuan mengidentifikasi, merumuskan, serta menganalisis problem-problem yang dihadapi. Menghimpun informasi sebanyak mungkin, menyusun rencana pemecahan masalah, memverifikasi, melakukan ekperimentasi, melakukan revisi atas rencana dan kegiatan. Seluruhnya dalam rangka proses pencapaian titik maksimal kegiatan dakwah menghadapi isu-isu HAM.

Beberapa dalil al-Quran serta sunnah, dan sejumlah kaidah umum dapat dirujuk para ulama dalam mengakomodir serta menjawab permasalahan yang berkembang. Dengan begitu Islam sebagai agama yang universal serta dinamis, mampu mengajukan jawaban terhadap semua persoalan dalam segala perbedaan tempat dan waktu serta situasi dan kondisi. Perkembangan saintek, bahkan akan semakin memperlihatkan nilai utama Islam dan tidak memungkinkan untuk tercerabut dari misinya sebagai agama rahmatan li al-'alamin.

\section{Tantangan HAM di Indonesia}

Indonesia yang mayoritas warganya menganut Islam, jika secara luas masyarakatnya kurang memahami dan tidak ingin mengerti dengan isu-isu HAM, maka sesungguhnya umat Islam terkesan melawan ajaran 
agamanya sendiri yang menempatkan nilai-nilai kemanusiaan pada posisi yang tinggi. Namun, sangat disayangkan seringkali HAM dipahami keliru bahkan ditafsir keliru sebagai "produk impor". Produk isu yang secara sengaja diinjeksikan oleh Barat kepada masyarakat penganut Islam guna mengaburkan nilai akidah yang diyakininya. Dengan bacaan seperti itu, tertolaknya isu HAM oleh umat Islam lebih disebabkan problem teologis.

Jika hendak ditelisik lebih dalam, hal tersebut tentunya tidak seluruhnya dapat dianggap benar. Terdapat variable lain yang dapat diajukan, yakni problematika politik Islam sejak akhir abad ke-15 yang memang mulai mengalami kemerosotan, meliputi beragam aspek kehidupan umat islam, seperti aspek sosial, politik, ekonomi, budaya, dan lain-lain. Ketika Barat membentuk Universal Declaration of Human Rights (UHDR) pada 1948, mereka tampil mempelopori HAM dan penegakannya, saat itu masyarakat Islam khususnya bangsa-bangsa Arab, merasa bahwa UHDR bukan bagian dari tuntunan Islam. Karenanya, misi HAM dipandang tidak sejalan dengan Islam.

Untuk konteks Indonesia, penegakan HAM masih menemukan sejumlah tantangan (R. Arifin 2018), yaitu:

a. Sistem pemerintahan belum dapat dipandang memiliki komitmen yang kuat terhadap ikhtiar penegakan HAM dan belum mampu mengimplementasikan secara efektif kebijakan tentang HAM, seperti yang ditugaskan oleh konstitusi.

b. Di sisi lain kemampuan masyarakat (civil society) masih lemah untuk proaktif secara demokratis menekan pemerintah, agar pemerintah dapat bersikap lebih serius dan peduli menjalankan agenda-agenda penegakan HAM. 
Dua cara yang dapat dilakukan sebagai ikhtiar dalam rangka penegakan HAM, yaitu dengan cara pencegahan dan penindakan (Nawawi, 2017). Upaya pencegahan antara lain dapat dilakukan dengan (Suteng, 2006);

a. Semakin melengkapi perundang-undangan HAM, termasuk di dalamnya ratifikasi sejumlah instrument HAM internasional.

b. Membuat beberapa lembaga atau institusi yang berfungsi memantau dan mengawasi pelaksanaan HAM. Institusi dimaksud dapat berupa institusi negara bersifat independen serupa Komnas HAM, maupun institusi-institusi bentukan masyarakat serupa organisasi non-pemerintah/LSM yang fokus bergerak pada pemantauan pemantauan HAM).

c. Membuat perundangan dan membentuk institusi peradilan HAM.

d. Mendorong pelaksanaan pendidikan HAM bagi warga negara melalui keluarga, sekolah serta upaya edukasi lainnya. Dalam konteks ini, seluruh media (media massa, media cetak, media elektronik) serta NGO yang berhikmad membangun kesadaran sosial, memperoleh peran sangat urgen.

Penegakan HAM dalam bentuk penindakan, antara lain dapat di dilaksanakan upaya dalam bentuk (Suteng, 2006);

1. Pelayanan, konsultasi, pendampingan, dan advokasi bagi masyarakat yang menghadapi kasus HAM. Dalam hal ini, lembaga-lembaga advokasi dan bantuan hukum serta organisasi non-pemerintah memainkan peran penting untuk bergerak dalam bidang advokasi masyarakat. 
2. Memastikan akses penerimaan pengaduan korban pelanggaran HAM. Komnas HAM, LBH, dan LSM HAM dalam hal ini memiliki peran penting,

3. Menguatkan investigasi, mencakup pencairan data, informasi, dan fakta berkaitan peristiwa yang patut diduga sebagai pelanggaran HAM. Upaya ini menjadi tugas Komnas HAM. Namun secara umum. baik LSM HAM maupun media, juga dapat melaksanakan investigasi independen.

4. Penyelesain perkara melalui perdamaian, negosiasi, mediasi, konsiliasi, dan penilaian ahli. Komnas HAM bertugas dan berwenang melakukan proses ini.

5. Mengupayakan penyelesaian perkara atau kasus pelanggaran HAM berat di pengadilan HAM melalui proses peradilan. Hal yang di anggap sebagai pelanggaran HAM berat meliputi kejahatan genosida, yakni; (1) menghancurkan, dan atau memusnahkan seluruh atau sebagian kelompok bangsa, ras, kelompok etnis dan kelompok agama dengan cara-cara tertentu; (2) kejahatan terhadap kemanusiaan berupa serangan meluas serta sistematik yang di tujukan langsung kepada warga atau masyarakat sipil).

\section{Peran Komunikasi Islam dalam Menghadapi Isu HAM}

Isu-isu kontemporer terkait masalah HAM tidak tepat bila disodorkan kepada halayak (mad'u) dalam bentuk pilihan; "harus menolak atau harus menerima". Jum'ah Amin Abdul Azis mengemukakan 10 kaidah dalam berdakwah, yang salah satu di antaranya menyebutkan; "pahamkan lebih dahulu sebelum membebankan" (Azis 2018). Khalayak harus lebih dahulu diberi pemahaman akan prinsip-prinsip Islam tentang manusia, terutama terkait dengan tiga soal; dari mana manusia, untuk apa mereka hidup di dunia dalam jumlah yang banyak, dan akan ke mana manusia setelah mati. 
Secara historis, kosmopolitanisme Islam pernah menjadi kenyataan sejarah, yang membentangkan jalan terbentuknya warisan kemanusiaan bagi seluruh kebudayaan (ruang dan waktu) yang tidak dikerdilkan oleh perpektif sempit dan parokialistik.

Komunikasi Islam sangat menentukan seberapa baik publik memahami dan menerima ajaran Islam untuk menjadi tuntunan kehidupan bersama. Semakin baik cara Islam dikomunikasikan, semakin baik penerimaan publik, baik pada level global maupun nasional. Dalam hal ini, dakwah menjadi aspek utama dalam mengkomunikasikan nilai-nilai kemanusiaan dalam Islam. Untuk maksud tersebut, tidak ada pilihan lain yang dapat dilakukan, kecuali dengan merekonstruksi pemahaman terhadap teks-teks dalil dan mengkontekstualisasikan dengan kondisi waktu dan tempat yang menjadi sasaran dakwah.

Hal tersebut di atas hanya bisa diwujudkan dengan dakwah yang terorganisir, bukan dakwah yang parsial digerakkan sendiri-sendiri oleh para $d a^{\prime} i$ sesuai keinginannya masing-masing.

Olehnya itu, ada beberapa hal yang dapat penulis ajukan, yang patut menjadi perhatian bersama dalam mendorong urgensitas komunikasi Islam atau dakwah dalam menghadapi isu-isu HAM khususnya di Indonesia. Hal tersebut adalah sebagai berikut;

1. Sangat relevan bila dakwah juga menjadi jalan melakukan kampanye global terkait Islam rahmatan li al-'alamin untuk menumbuhkan semangat kemanusiaan universal dalam hal ini HAM. Al-Quran dengan konsep rahmatan li al-'alamin mengandung makna serta konsekwensi bahwa al-Quran mestinya selalu menjadi relevan sepajang masa pada setiap ruang kebudayaan di dunia. Teks-teks al-Qur'an mestinya dapat 
ditafsir sesuai konteks ruang dan waktu. Kampanye Islam rahmatan li al-'alamin dirasakan akan menguntungkan umat Islam khususnya di Indonesia dalam menghadapi isu HAM karena bisa membantu meredakan berbagai konflik yang melibatkan umat Islam, baik ditingkat lokal, nasional maupun internasional.

2. Memperkuat kelembagaan dakwah untuk lebih mengintensifkan kampanye Islam rahmatan li al-'alamin agar diimplementasikan lewat pendekatan sikap tawasuth (moderat) dan i'tidal (lurus atau adil), tawazun (seimbang), tasamuh (toleran), serta tasyawur (bermusyawarah). Apalagi, Islam sendiri pada dasarnya mengajarkan konsep ukhuwah (persaudaraan) kepada umat manusia di seluruh dunia.

3. Membentuk jejaring da'i yang khusus berkonsentrasi pada isu HAM, baik ditingkat global, nasional, maupun regional. Umat Islam di Indonesia, tetap harus aktif terlibat di dalam proses global yang tengah berlangsung terkait isu HAM, menjadi bagian penting dan berkontribusi positif dalam kerangka Global Civil Society, sembari melakukan kampanye global Islam rahmatan li al'alamin dan kemanusiaan universal, di samping juga bersikap kritis terhadap dampak negative yang muncul dari isu-isu HAM.

4. Kegiatan dakwah harus dikonsolidasikan antara kelompokkelompok organisasi dakwah, untuk menyusun target capaian dakwah sesuai sasaran tempat dan kondisi sosial budaya yang dihadapi.

5. Dakwah tematik semisal HAM dan isu-isu kontemporer serupa, perlu lebih diorganisir dan digencarkan, sehingga tidak terjadi 
pemahaman yang "hitam-putih" di tengah ummat yang justru mempertajam konflik.

Kegiatan dakwah sebagai bagian dari upaya mengkomunikasikan Islam kepada publik, masih memerlukan penyesuaian terus menerus sesuai dengan perkembangan jaman. Sangat diharapkan dengan upaya-upaya yang maksimal, Islam tidak menjadi agama menakutkan yang acap kali dihubungkan dengan aktifitas terorisme dan fundamentalisme sebagai kelompok yang mengabaikan nilai kemanusiaan universal.

\section{SIMPULAN}

Merujuk pada uraian singkat di atas, penulis mencoba mengemukakan beberapa kesimpulan. Pertama; konsep penegakan HAM dalam Islam sebagai rahmatan li al-'lamin dapat ditemui dalam sejumlah ayat al-Qur'an seperti; hak hidup, hak perlindungan diri, hak persamaan dan kebebasan, hak kesetaraan laki-laki dan perempuan, hak keluarga, hak anak, hak memperoleh pendidikan, kebebasan beragama, hak mencari suaka, hak mendapatkan pekerjaan, hak memperoleh perlakuan yang sama, hak kepemilikan, serta hak tahanan. Selain itu, secara praktek terlihat dalam Piagam Madinah atau al-Dustur al-Madinah dan Deklarasi Cairo atau The Cairo Declaration. Kedua; tantangan HAM di Indonesia masih sangat besar. Masih membutuhkan penguatan komitmen atas upaya menegakkan HAM dan komitmen untuk implementasi kebijakan HAM secara efektiif, sebagaimana diamanatkan oleh konstitusi. Ketiga; peran komunikasi Islam dalam menghadapi isu HAM semakin relevan dan urgen. Dakwah harus diolah lebih professional dan menjadi ruang bagi kampanye Islam rahmatan li al-'alamin untuk penegakan HAM, serta mengedukasi masyarakat dalam penegakan HAM. Umat Islam di Indonesia harus berkontribusi dalam 
mengkomunikasikan Islam yang menjunjung tinggi nilai-nilai kemanusiaan.

\section{REFERENCE}

Al-Maududi, Abu A 'la. 1998. Hak Asasi Manusia Dalam Islam. 1st ed. Jakarta: YAPI.

Alfaruqi, Daniel. 2017. "Korelasi Hak Asasi Manusia Dan Hukum Islam." Salam; Jurnal Sosial \& Budaya Syar-i 1V(1).

Arifin, Ridwan. 2018. “Tinjauan Atas Permasalahan Penegakan Hukum Dan Pemenuhan Hak Dalam Konteks Universalime Dan Relativisme Hak Asasi Manusia Di Indonesia." Legality 26(1).

Arifin, Syamsul. 2011. "Diskursus Islam Dan Hak Asasi Manusia Di Indonesia Perspektif Kebebasan Beragama/Berkeyakinan." Jurnal UMM 14(2).

Atqiya, Naimatul. 2014. “HAM Dalam Perspektif Islam." Islamuna 1(2).

Azis, Jum'ah Amin Abdul. 2018. Al-Da'wah; Qawaid Wa Ushul. Terjemahan. Solo: PT. Era Adicitra Intermedia.

Kasdi, Abdurrahman. 2014. "Maqasyid Syari'ah Perspektif Pemikiran Imam Syatibi Dalam Kitab Al-Muwafaqat." Yudisia 5(2).

Nawawi, Asror. 2017. “Komnas HAM: Suatu Upaya Penegakan HAM Di Indonesia." Jurnal Hukum Progresif 9(1).

Pengestuti, Naniek \& Khamdan, Muh. 2017. Konsep Dasar HAM. Jakarta: Badan Pengembangan Sumber Daya Manusia Hukum dan HAM.

Rosyada, Dede et all. 2005. Demokrasi, Hak Asasi Manusia Dan Masyarakat Madani. Jakarta: ICCE UIN Syarif Hidayatullah.

Rukmana, Aan. 2019. "Islam Dan Hak Asasi Manusia." Islamic Cultural Centre Jakarta. https://icc-jakarta.com/2019/03/22/islam-dan-hak-asasimanusia/.

Sudjana, Eggi. 2002. Hak Dalam Perspektif Islam, Mencari Universalitas HAM Bagi Tatanan Modernitas Yang Hakiki. 1st ed. Jakarta: Nuansa Madani.

Suhaili, Achmad. 2019. "Hak Asasi Manusia (HAM) Dalam Penerapan Hukum Islam Di Indonesia." Jurnal Ilmu Al Qur'an dan Hadist 2(2).

Suteng, Bambang. 2006. Pendidikan Kewarganegaraan. 1st ed. Jakarta: Erlangga. 
Kuriositas: Media Komunikasi Sosial dan Keagamaan

Vol. 13 No.2, Desember 2020: h.198-218

Triwahyuningsih, Susani. 2018. "Perlindungan Dan Penegakan Hak Asasi Manusia (Ham) Di Indonesia." Jurnal Hukum Legal Standing 2(2).

Washil, Izzuddin \& Ahmad, Khoirul Fata. 2017. “HAM Islam Dan DUHAM PBB." Miqot XLI(2). 